\title{
Analysis of the Altman, Zmijewski and Fulmer Models in Predicting Financial Distress in PT Semen Padang
}

\author{
Rangga Putra Ananto ${ }^{1}$, Fera Sriyunianti ${ }^{2}$, Ferdawati ${ }^{3}$, Hamru Bin Af ${ }^{4}$ \\ \{rangga@pnp.ac.id ${ }^{1}$,vra_sri@yahoo.com²,f3rd4@yahoo.com ${ }^{3}$, hamroebinaf@gmail.com ${ }^{4}$ \}
}

Accounting of Department, State Polytechnic of Padang 1234

\begin{abstract}
The purpose of this research is to see and give an overview of the potential financial distress that might occur at PT Semen Padang. This research is quantitative descriptive. The data used in the form of secondary data and pooled data. Data collection techniques carried out with documentation techniques. The object of this research is PT Semen Padang for the period 2014-2018. The results of this study are of the three Altman, Zmijewski and Fulmer models all stating that PT Semen Padang is in a non-distress condition.
\end{abstract}

Keywords: Financial Distress, Altman, Zmijewski, Fulmer

\section{Introduction.}

Financial Reports published by companies are one source of information about the company's financial position, performance and changes in the company's financial position, which is very useful to support the right decision making. There are many financial statement analysis techniques, one way to do is with financial ratio analysis. Financial ratio analysis is useful to control the effect of differences between companies or between time, invest in related theories, and examine the empirical relationship between financial ratios and estimates or predictions of certain variables such as financial distress or financial distress. The condition of financial difficulties and the decline in performance and financial distress of a company can be seen and measured through financial statements. [1].

The condition of the mining sector in Indonesia has recently declined. As quoted on CNN Indonesia, that the mining and quarrying industry recorded a decline in growth amid the shiny national economy. The Central Statistics Agency (BPS) said the mining and quarrying sector experienced a negative contraction of 0.49 percent. In fact, economic growth in the first quarter of 2017 reached 5.01 percent, improved compared to the same period last year, which was 4.92 percent.

BPS Chief Suhariyanto said the two sectors were contracted because of two large companies, namely PT Freeport Indonesia (PTFI) and PT Amman Mineral Nusa Tenggara (AMNT), former PT Newmont Nusa Tenggara, had experienced a production decline of up to 60 percent since last January along with the expiration of export licenses concentrate for the company. The mining and quarrying sector is the only sector that experienced a negative contraction of 0.49 percent. This is also due to a decrease in copper and gold production by PT Freeport Indonesia and PT Amman [2].

The same condition was also seen in PT Semen Padang, which also experienced a decline in financial performance. As quoted from finance.detik.com, PT Semen Indonesia recorded a decline in the company's net profit in the third quarter of 2017 to Rp 1.4 trillion from the same period the previous year of $\mathrm{Rp} 2.9$ trillion. This decline in net profit has occurred since 2014. Citing SMGR's financial statements for the third quarter of 2017, the company's revenue was recorded at Rp 20.5 trillion, up slightly compared to the same period last year of Rp 19 trillion. However, the company's financial burden swelled to Rp 522 billion from the previous period of Rp 252 billion. Net profit in the third quarter of 2017 was recorded at Rp 1.47 trillion, down significantly compared to the same period last year of Rp 2.9 trillion[3]. 
The above conditions provide a signal that a decline in financial performance. If this condition is allowed to continue on a long-term basis, it will lead to financial distress or financial distress. Financial distress of a company can be detected from the beginning, so that if this possibility can be known earlier, a company will be able to take appropriate steps so that financial distress conditions can be avoided.

Financial distress of a company can be predicted with a variety of existing models. The financial distress prediction model is very important for companies, investors, creditors and the government. These parties usually react to the distress signal. These signals include decreasing corporate profits. One of the most commonly used financial distress prediction models is the Altman Z Score Model. Altman conducted research to develop predictions for financial distress of the company. The model called z-score in its original form is a linear model with financial ratios that are weighted to maximize the ability of the model to predict. This model basically wants to find the value of " $\mathrm{Z}$ " which is a value that shows the condition of the company, whether in a healthy state or not and shows the performance of the company which also illustrates the company's prospects in the future. Another model that can be used is the Zmijewski model using ratio analysis that measures the performance, leverage, and liquidity of a company for its prediction model. This model will look for the value "X" which is a value that shows the condition of the company, whether it is potentially bankrupt or not. The Fulmer model can also be used in predicting financial distress, where this model uses the ratio of retained earnings, cash flow, total assets and total debt. This model will look for the value of "H Score" which shows the potential financial distress that exists in the company.

Research on financial distress prediction has been done a lot. Especially by using the Altman and Zmijewsky models. However, research on financial distress prediction using the Fulmer model is still limited. The use of the Fulmer Model is what distinguishes this study from previous research. The condition of PT Semen Padang's financial performance which has been declining in recent years, may potentially lead to financial distress. So that this research is expected to give an idea, about the potential for financial distress that might occur in the future.

\section{Literature review}

\section{Financial statements}

Based on the Statement of Financial Accounting Standards [4], financial statements are a structured presentation of the financial position and financial performance of an entity. The purpose of financial statements is to provide information about the financial position, financial performance and cash flow of the entity that is useful for most users of the report in making economic decisions. The financial statements also show the results of management's responsibility for the use of resources entrusted to them.

\section{Financial Ratio Analysis}

Ratio analysis describes a relationship or balance between a certain amount with another amount, and by using analysis tools in the form of ratios will be able to provide an analysis to the analyst about the good or bad condition of a company's financial position, especially when compared to the comparative ratio numbers used as a standard [5].

\section{Financial Distress}

Financial distress is a condition where the company's finances are in an unhealthy state or crisis. Financial distress occurs before financial distress. Financial distress itself is usually interpreted as a situation or situation where the company fails or is no longer able to meet the obligations of the debtor because the company experiences shortages and insufficient funds to run or continue its business so that the economic goals to be achieved by the company can be achieved, namely profit, because with profits that obtained by the company can be used to return loans, can finance the company's operations and obligations that must be fulfilled can be covered with profits or assets owned.

Financial distress is the stage of decline in financial conditions experienced by a company, which occurred before the bankruptcy or liquidation. This condition is generally characterized by, among others, delays in shipping, declining product quality, and postponement of bill payments from banks. If the condition of financial distress is known, it is hoped that action can be taken to improve the situation so that the company will not enter a more difficult stage such as bankruptcy or liquidation [6]. 


\section{Altman's Z Score Model}

Altman was the first to implement Multiple Discriminant Analysis. The first research was carried out in 1968. The Altman model was changed several times, and the last was changed in 1995 called the Modified Altman Model. The Altman model is the most widely used model in predicting financial distress[7]. The formula is as follows:

Information:

$$
Z=6,56 X_{1}+3,26 X_{2}+6,72 X_{3}+1,05 X_{4}
$$

$$
\begin{array}{ll}
\mathrm{Z} & =\text { bankrupcy index } \\
\mathrm{X}_{1} & =\text { working capital / total asset } \\
\mathrm{X}_{2} & =\text { retained earnings / total asset } \\
\mathrm{X}_{3} & =\text { earning before interest and taxes / total asset } \\
\mathrm{X}_{4} & =\text { book value of equity / book value of total debt }
\end{array}
$$

The classification of a distress and non distress company is based on the Z-score of the Modified Altman model, namely:

If the value of $Z "<1.1$, including the distress company.

If the value is $1.1<\mathrm{Z}$ " $<2.6$ then it is included in the gray area (it cannot be determined whether the company is distress or non distress).

If the value of $Z ">2.6$, including companies that are non distress.

\section{Zmijewski Model}

Zmijewski's (1984) model uses ratio analysis that measures a company's performance, leverage, and liquidity for its prediction model. Zmijewski used probit analysis that was applied to 40 companies that had gone bankrupt and 800 companies that had not gone bankrupt [8]. Models that have been successfully developed are as follows:

Information:

$$
X=-4.3-4.5 X_{1}+5.7 X_{2}-0.004 X_{3}
$$

$$
\begin{array}{ll}
\mathrm{X}_{1} & =\text { ROA (return on asset) } \\
\mathrm{X}_{2} & =\text { Leverage (debt ratio) } \\
\mathrm{X}_{3} & =\text { Likuiditas (current ratio) }
\end{array}
$$

The classification of a distress and non distress company is based on the $\mathrm{X}$ score of the Zmijewski model score, namely:

If $\mathrm{X} \geq 0$, the company is classified as "distress"

If $\mathrm{X}<0$, the company is classified as "non distress"

\section{Fulmer Model}

The financial distress prediction model developed by Fulmer is:

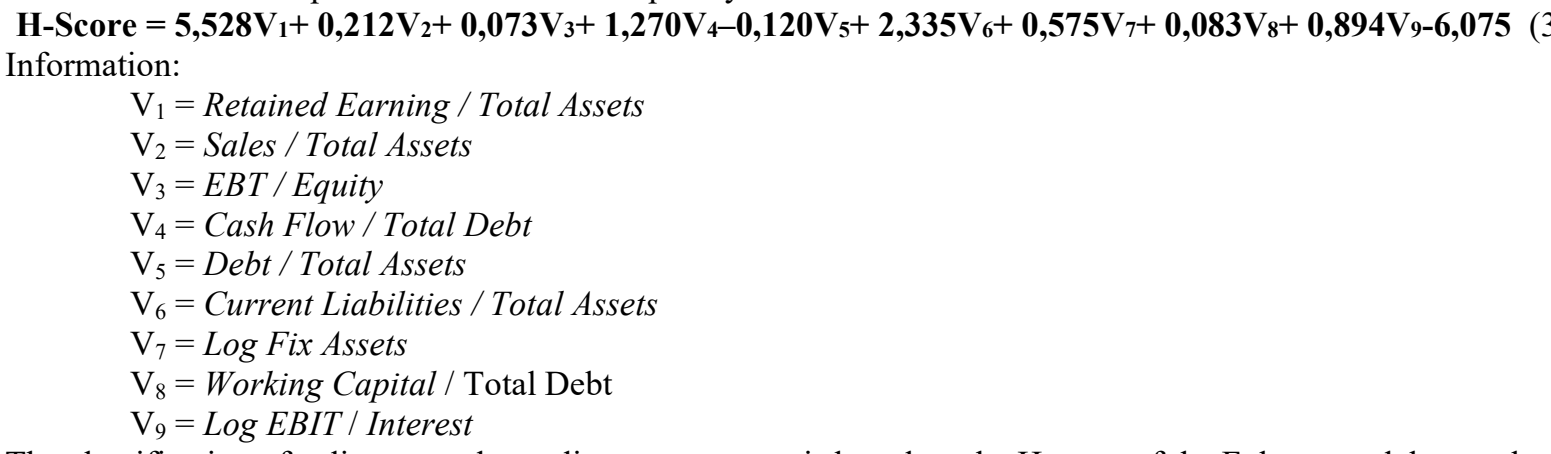

The classification of a distress and non distress company is based on the H score of the Fulmer model, namely:

If $\mathrm{H}$ Score $<0$, the company is classified as "distress"

If $\mathrm{H}$ Score $>0$, the company is classified as "not distress" 


\section{Framework}

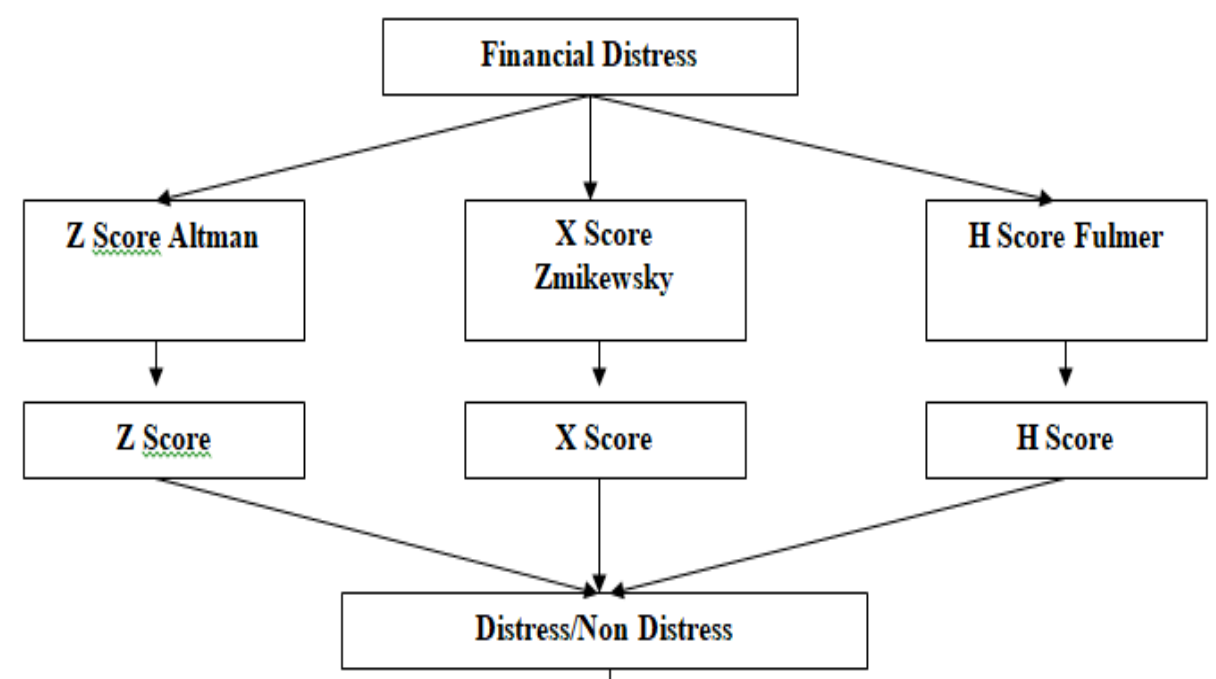

Figure 1. Framework

\section{Methodology}

\section{Types of research}

This research is quantitative descriptive. Understanding descriptive methods proposed by [9], states that the descriptive method is as follows: "Descriptive method is a method used to describe or analyze a research result but not used to make clearer conclusions".

This research is quantitative descriptive. Understanding descriptive methods proposed by [9], states that the descriptive method is as follows: "Descriptive method is a method used to describe or analyze a research result but not used to make clearer conclusions".

\section{Data Type}

The data used are secondary data and pooled data. Secondary data is data obtained by researchers indirectly through intermediary media (obtained and recorded by other parties). Secondary data is generally in the form of evidence, historical records or reports that have been compiled in archives (documentary data) which are published and which are not published. Pooled data is a combination of times series data and cross section. Time series data is a collection of data from a particular phenomenon that is obtained in a certain time interval, and cross section data is a set of data from a particular phenomenon in just one period of time.

\section{Data collection technique}

In this study, data collection was carried out using documentation techniques. Documentation technique is a technique that is carried out by collecting data on the financial statements of a company which is a research sample through the Representative Office of the Indonesian Stock Exchange in Padang and for other supporting materials using internet facilities by accessing the company's official websites and information from other media $[10]$.

\section{Result and Discussion}

\section{Altman Model Calculation Results}

The following is the result of the calculation of financial distress using the Altman model at PT Semen Padang in the 2014-2018 period 
Table 1. PT Semen Padang Z-score Calculation Results for the 2014-2018 period

\begin{tabular}{|c|c|c|c|c|c|c|}
\hline Years & $\mathbf{X}_{\mathbf{1}}$ & $\mathbf{X}_{\mathbf{2}}$ & $\mathbf{X}_{\mathbf{3}}$ & $\mathbf{X}_{\mathbf{4}}$ & Z-score & Interpretation \\
\hline 2014 & 0.21 & 0.66 & 0.20 & 2.57 & 7.62 & Non distress \\
\hline 2015 & 0.01 & 0.56 & 0.14 & 1.52 & 4.40 & Non distress \\
\hline 2016 & 0.03 & 0.50 & 0.11 & 1.13 & 3.73 & Non distress \\
\hline 2017 & 0.03 & 0.47 & 0.08 & 0.95 & 3.31 & Non distress \\
\hline 2018 & 0.02 & 0.53 & 0.12 & 1.23 & 3.94 & Non distress \\
\hline
\end{tabular}

Source: Processed Data, 2019

Based on the table above, it shows that PT. Semen Padang is in a non-distress state with an average Z-score above 2.6 or $\mathrm{Z}>2.6$ which is categorized as a healthy company. The highest Z-score occurred in 2014 with a value of 7.62 while the lowest value occurred in 2017 with a score of 3.31. Here is a graph of the Z-score of PT. Semen Padang for the period 2014-2018.

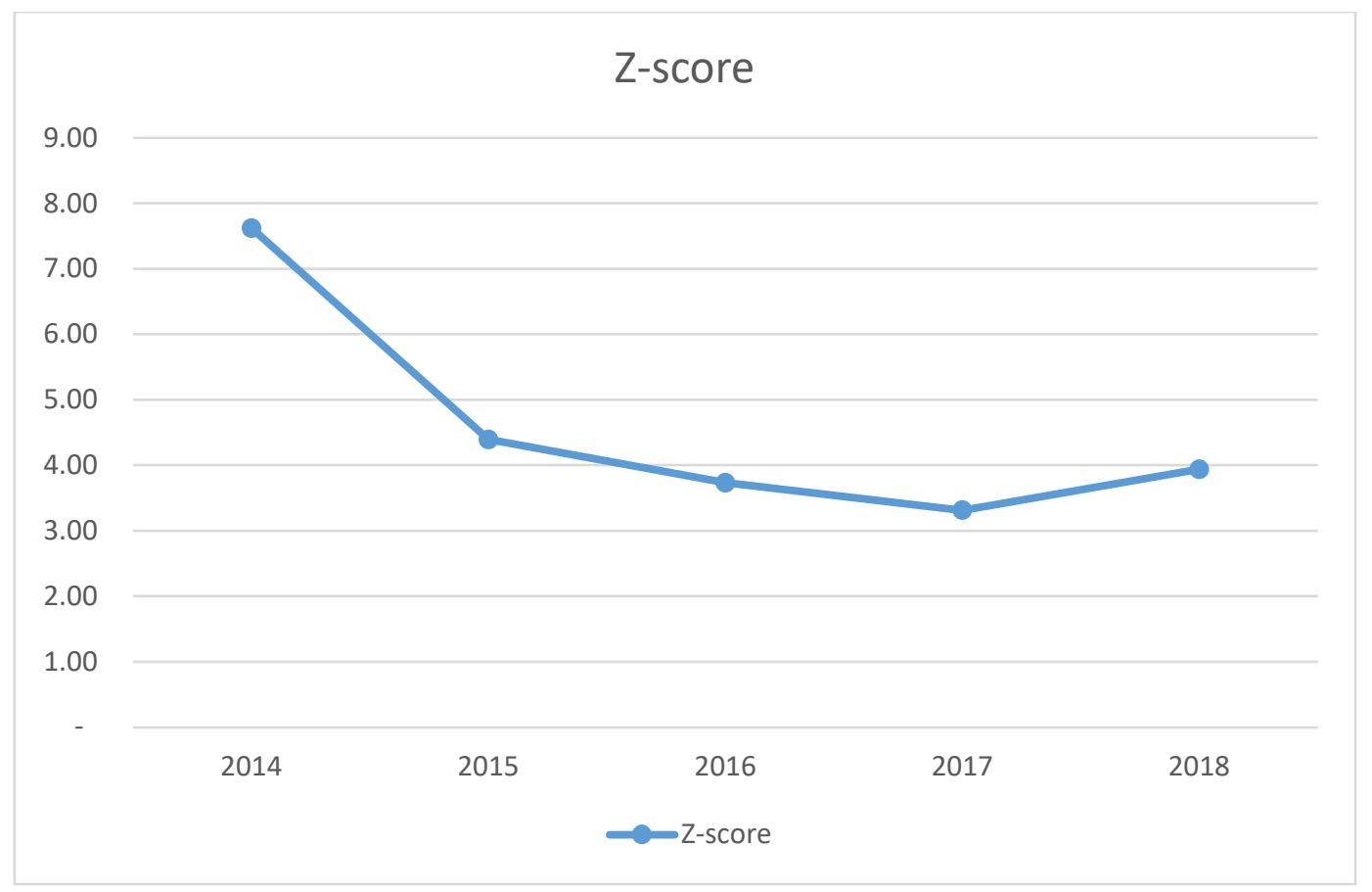

Figure 2. Z-score of PT. Semen Padang for the period 2014-2018

Based on the Z-score chart, PT. Semen Padang has decreased the 2014-2017 Z-score as shown in the graph above. In 2015 PT. Semen Padang experienced a significant decrease in Z-score of 3.23 from the previous year. This is due to the X1 value where the working capital owned by the company is too small with a value of 0.01 due to an increase in the company's total current debt but the total assets of the company have decreased so that the available working capital of current assets is small. Small working capital will affect the ratio X1, the smaller the working capital, the smaller the value of X1 owned. A small X1 value will directly affect the Z-score. In 2015 PT. Semen Padang has a Z-score of 4.40 which means the company is in a non-distress or healthy condition. In 2016 the company experienced a Z-score decline of 3.73 this is because the company experienced an increase in debt of Rp. 1,388,728,483,000. This resulted in a significant decrease in the X4 ratio of 0.39 from 1.52 to 1.13 . In 2017 the company still experienced a decline in the Z-score to 3.31, this was due to an increase in debt of Rp.8,698,688,336,000 which had an impact on the reduction in the X4 ratio from 1.13 to 0.95 . In 2018 the company experienced an increase in Z-score to 3.94 due to a significant increase in profit before tax and a decrease in the level of corporate debt of Rp. will increase too.

To find out the percentage of PT Semen Padang's financial condition for the 2014-2018 period using the Altman model, see the following table: 
Table 2. Percentage of Interpretation of Z-score

\begin{tabular}{|l|l|l|l|}
\hline No & Interpretation & Percentage & Amount \\
\hline 1 & Distress & $0 \%$ & 0 \\
\hline 2 & Grey Area & $0 \%$ & 0 \\
\hline 3 & Non Distress & $100 \%$ & 5 \\
\hline
\end{tabular}

Source: Processed Data, 2019

Based on the above table, it can be seen that the percentage score of PT Semen Padang in the 2014-2018 period using the Altman model of the total five periods is all in a non-distress condition with a percentage level reaching $100 \%$.

\section{Zmijewski Model Calculation Results}

Table 3. Calculation Results of PT Semen Padang's X-score for the 2014-2018 period

\begin{tabular}{|l|l|l|l|l|l|}
\hline \multicolumn{1}{|c|}{ Years } & $\mathbf{X}_{\mathbf{1}}$ & $\mathbf{X}_{\mathbf{2}}$ & $\mathbf{X}_{\mathbf{3}}$ & $\mathbf{X}$-score & \multicolumn{1}{|c|}{ Interpretation } \\
\hline 2014 & 0.901 & 1.596 & 0.008 & $(3.612)$ & Non distress \\
\hline 2015 & 0.619 & 2.261 & 0.004 & $(2.662)$ & Non distress \\
\hline 2016 & 0.509 & 2.674 & 0.004 & $(2.139)$ & Non distress \\
\hline 2017 & 0.367 & 2.917 & 0.005 & $(1.755)$ & Non distress \\
\hline 2018 & 0.549 & 2.554 & 0.004 & $(2.300)$ & Non distress \\
\hline
\end{tabular}

Source: Processed Data, 2019

Based on the results of the above table, the highest X-score of PT Semen Padang occurred in 2017 with a value of (1.75) while the lowest value occurred in 2014 with a value (3.61). If the value of $X>0$, the company can be said or classified in a state of distress, conversely if $X<0$, the company is predicted not to be in a state of distress. Based on the above table, it can be interpreted that the company did not experience distress because based on the data above there was no X-score value of PT. Semen Padang is above zero or $>0$. The following is a chart of PT Semen Padang's X-score for the 2014-2018 period.

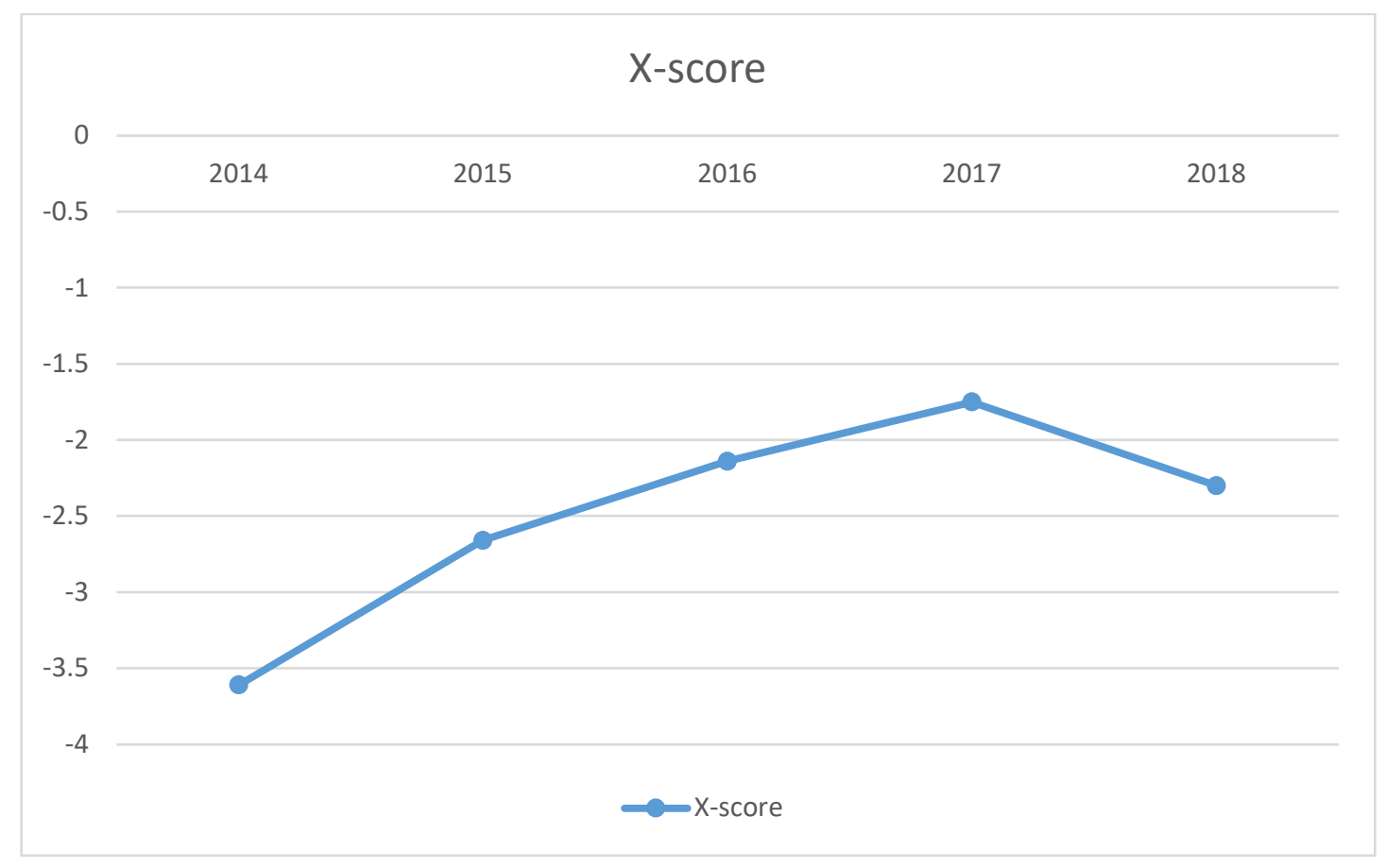

Figure 3. X-score of PT Semen Padang in the 2014-2018 period 
Based on the graph above, the value of X-score of PT Semen Padang tends to decrease. in 2015 the value of X-score of PT Semen Padang of (2.66) decreased from 0.95 the previous year from (3.61) a year because this was due to an increase in current debt of Rp. 823,162,471,000. In 2016 the X-score of PT Semen Padang continued to decline with an X-score of (2.14), this was due to an increase in the value of debt and a decrease in corporate profits. In 2017 the value of X-score of PT Semen Padang Still declined with the value (1.75) and is the lowest score of the five years. In 2018 PT Semen Padang experienced an increase in X-score with a value (2.30) this was due to an increase in profits earned by the company amounting to Rp.391,000,000,000, and a decrease in debt of Rp.713,530,000,000. Based on the results of the Zmijeski model financial distress prediction calculation of the five years, the company can be predicted in a non-distress condition.

To find out the percentage of the financial condition of PT Semen Padang in the 2014-2018 period using the Zmijewski model, see the following table:

Table 4. Percentage of Interpretation of X-score

\begin{tabular}{|l|l|l|l|}
\hline No & Interpretation & Percentage & Amount \\
\hline 1 & Distress & $0 \%$ & 0 \\
\hline 2 & Non Distress & $100 \%$ & 5 \\
\hline
\end{tabular}

\section{Source: Processed Data, 2019}

Based on the table above, it can be seen that the percentage score of PT Semen Padang in the 2014-2018 period using the Zmijewski model of a total of five periods or five data are all in a non-distress condition with a percentage level reaching $100 \%$.

\section{Fulmer Calculation Results}

Table 5. Results of Analysis by the Fulmer Method of PT. Semen Padang Period 2014-2018

\begin{tabular}{|c|c|c|c|c|c|}
\hline Years & $\mathbf{2 0 1 4}$ & $\mathbf{2 0 1 5}$ & $\mathbf{2 0 1 6}$ & $\mathbf{2 0 1 7}$ & $\mathbf{2 0 1 8}$ \\
\hline $\mathrm{V}_{1}$ & 3.66 & 3.10 & 2.75 & 2.61 & 2.92 \\
\hline $\mathrm{V}_{2}$ & 0.23 & 0.19 & 0.14 & 0.14 & 0.15 \\
\hline $\mathrm{V}_{3}$ & 0.02 & 0.02 & 0.01 & 0.01 & 0.01 \\
\hline $\mathrm{V}_{4}$ & 0.65 & 0.61 & 0.42 & 0.10 & 0.37 \\
\hline $\mathrm{V}_{5}$ & 0.03 & 0.05 & 0.06 & 0.06 & 0.05 \\
\hline $\mathrm{V}_{6}$ & 0.56 & 0.71 & 0.48 & 0.49 & 0.54 \\
\hline $\mathrm{V}_{7}$ & 7.15 & 7.29 & 7.38 & 7.40 & 7.40 \\
\hline $\mathrm{V}_{8}$ & 0.83 & 0.02 & 0.06 & 0.07 & 0.04 \\
\hline $\mathrm{V}_{9}$ & 1.35 & 1.09 & 0.99 & 0.66 & 0.69 \\
\hline H-score & $\mathbf{8 . 3 5}$ & $\mathbf{6 . 9 1}$ & $\mathbf{6 . 1 0}$ & $\mathbf{5 . 3 4}$ & $\mathbf{4 . 9 9}$ \\
\hline Interpretation & Non & & & & \multirow{2}{*}{ Non distress } \\
\hline
\end{tabular}

Source: Processed Data, 2019

Based on the above H-score calculation table, the highest $\mathrm{H}$-score value occurred in 2014 with a value of 8.35 and the lowest value occurred in 2018 with a value of 4.99 . The following is a chart of the PT Semen Padang H-score for the 2014-2018 period. 


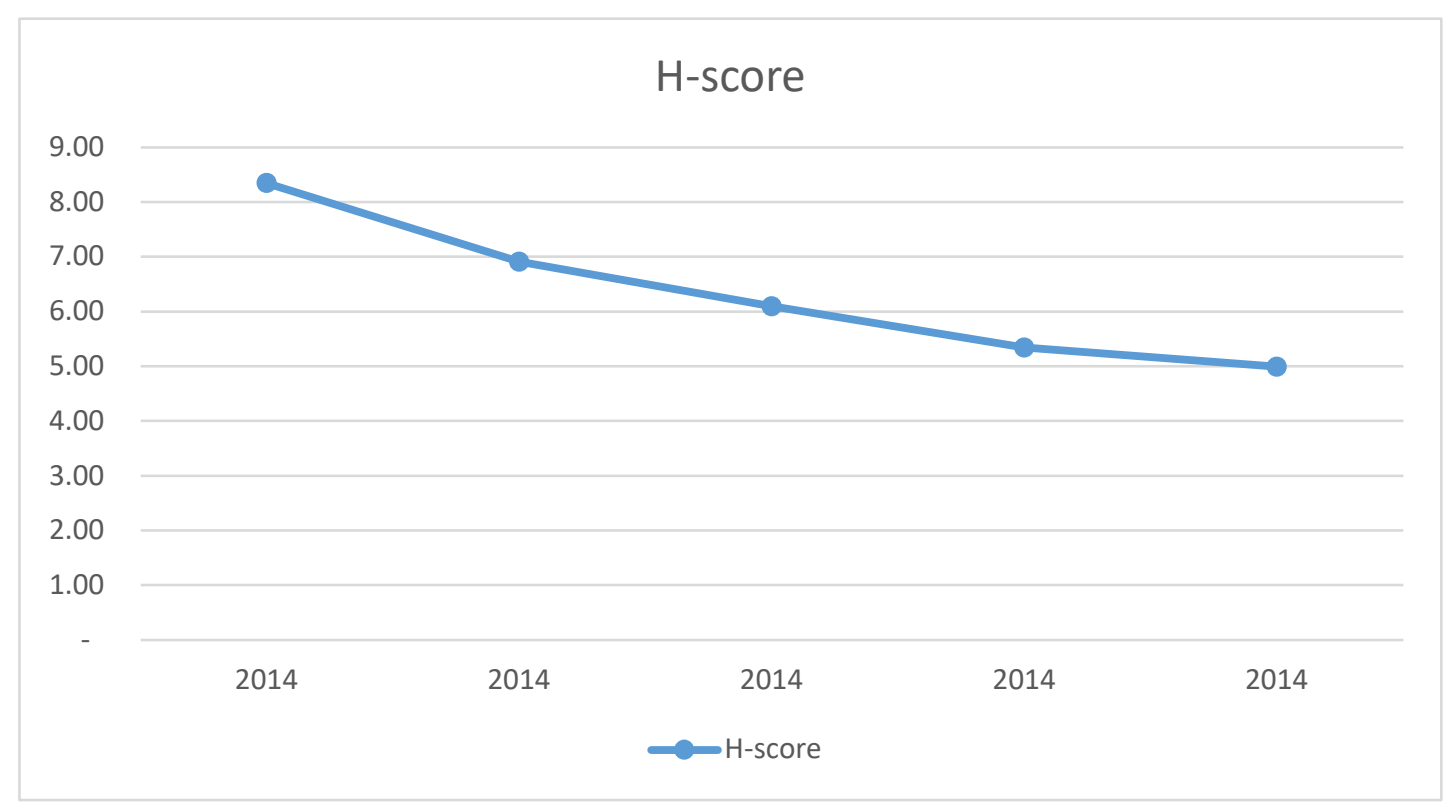

Figure 4. PT Semen Padang H-score value for the 2014-2018 period

Based on the graph above, the results of the calculation of H-score of PT Semen Padang in 2014-2018 have decreased every year but despite the decline in the H-score of PT Semen Padang is still in a non-distress condition. The biggest decrease occurred in 2015 with a decrease in score of 1.44. Based on the calculation results of the Fulmer model above it can be concluded that PT Semen Padang in the 2014-2018 period was in a non-distress condition.

To find out the percentage score of the Fulmer model at PT Semen Padang in the 2014-2018 period, see the following table:

Table 6. Percentage of interpretation of the H-score

\begin{tabular}{|l|l|l|l|}
\hline No & Interpretation & Percentage & Amount \\
\hline 1 & Distress & $0 \%$ & 0 \\
\hline 2 & Non Distress & $100 \%$ & 5 \\
\hline
\end{tabular}

\section{Source: Processed Data, 2019}

Based on the above table, it can be seen that the percentage score of PT Semen Padang in the 2014-2018 period using the Fulmer model of a total of five periods or five data are all in a non-distress condition with a percentage level reaching $100 \%$.

\section{Comparison of Each Model}

Table 7. Comparison of Altman, Zmijewski and Fulmer Models at PT Semen Padang in the 2014-2018 period

\begin{tabular}{|c|c|c|l|l|l|l|l|}
\hline \multirow{2}{*}{ Years } & \multicolumn{3}{|c|}{ Altman Model } & \multicolumn{2}{c|}{ Zmijewski Model } & \multicolumn{2}{c|}{ Fulmer Model } \\
\cline { 2 - 8 } & Distress & $\begin{array}{l}\text { Grey } \\
\text { Area }\end{array}$ & $\begin{array}{l}\text { Non } \\
\text { distress }\end{array}$ & Distress & $\begin{array}{l}\text { Non } \\
\text { distress }\end{array}$ & Distress & $\begin{array}{l}\text { Non } \\
\text { distress }\end{array}$ \\
\hline 2014 & & & $\sqrt{ }$ & & $\sqrt{ }$ & $\sqrt{ }$ \\
\hline 2015 & & & $\sqrt{ }$ & & $\sqrt{ }$ & & $\sqrt{ }$ \\
\hline 2016 & & & $\sqrt{ }$ & & $\sqrt{ }$ & & $\sqrt{ }$ \\
\hline 2017 & & & $\sqrt{ }$ & & $\sqrt{ }$ & $\sqrt{ }$ \\
\hline 2018 & & & $\sqrt{ }$ & & $\sqrt{ }$ & $\mathbf{0}$ & $\mathbf{5}$ \\
\hline Amount & $\mathbf{0}$ & $\mathbf{0}$ & $\mathbf{5}$ & $\mathbf{0}$ & $\mathbf{5}$ & $\mathbf{0} \%$ & $\mathbf{1 0 0 \%}$ \\
\hline Percentage & $\mathbf{0 \%}$ & $\mathbf{0 \%}$ & $\mathbf{1 0 0 \%}$ & $\mathbf{0}$ & $\mathbf{1 0 0 \%}$ & $\mathbf{0} \%$ \\
\hline
\end{tabular}

Source: Processed Data, 2019 
Based on the table above, the three models say that PT Semen Padang in the 2014-2018 period was in a nondistress condition. Altman model gives a higher portion of the value of the ratio of earn before interest and tax to total assets on average earnings before interest to tax PT Semen Padang has a pretty good value there is no EBIT that has a negative value so the results of the score using the Altman model are in a non-distress condition. In the fulmer model of the five-year sample, the results also show that PT Semen Padang is in a non-distress condition. Fulmer himself gives the highest coefficient on retained earnings to total assets. At PT Semen Padang, the profit balance shows an increase from year to year so that it will greatly affect the results of the fulmer model. Therefore Fulmer predicts that PT Semen Padang is in a non-distress condition. Similar to the Zmijewski model the results of the calculation of this model predict that PT Semen Padang in the 2014-2018 period is in a nondistress condition. This is caused by the Zmijewski model giving a higher portion of the value of leverage. Although the leverage value of PT Semen Padang is quite high, PT Semen Padang is still in a non-distress condition.

\section{Conclusion}

Based on the results of the calculation of the three models above, it can be concluded that the Altman model shows that PT Semen Padang in the 2014-2018 period was in a non-distress condition. Zmijewski's model predicts that PT Semen Padang in the 2014-2018 period will be in a non-distress condition and the Fulmer model also predicts that PT Semen Padang in the 2014-2018 period will be in a non-distress condition. This shows that the three models equally predict that PT Semen Padang in the 2014-2018 period is in a non-distress condition.

\section{References}

[1] Y. Agus, "Analisis Rasio Keuangan Untuk Memprediksi Kondisi Financial Distress Perusahaan Yang Terdaftar Di Bursa Efek Indonesia Dengan Menggunakan Regresi Logistik,” 2010.

[2] C. Indonesia, "Ekonomi Tumbuh, Industri Tambang Malah Melorot." 2017.

[3] Finance.detik.com, "Laba Turun, Semen Indonesia Lakukan Efisiensi." 2017.

[4] I. A. Indonesia, Standar Akuntansi Keuangan. Jakarta: Salemba Empat, 2016.

[5] K. . Subramanyam, Financial Statement Analysis, Eleventh. Singapore: MC Graw Hill, 2016.

[6] H. Platt and P. M. B, "Predicting Financial Distres," J. Financ. Serv. Prof., vol. 56, pp. 12-15, 2002.

[7] E. Altman, Corporate Financial Distress and Financial distress. A Complete Guide to Predicting \& Avoiding Distress and Profiting from Financial distress., Second. Canada, 1993.

[8] M. . Zmijeswsky, "Methodological Issues Related to the Estimastion of Financial Distress Prediction Models.," J. Account. Res. Suppl., vol. 22, pp. 59-82, 1984.

[9] Sugiyono, Metode Penelitian Kombinasi (Mixed Methods). Bandung: Alfabeta, 2012.

[10] IDX, "No Title." 2019. 